\title{
Teacher Trainees Perceptions of Think-Pair-Share Technique in Teaching Classification of Living Organisms in Colleges of Education - Ghana
}

\author{
Joseph Parker ${ }^{1 *}$, Isaac Asare ${ }^{2}$ \\ ${ }^{1}$ Department of Science Education, Enchi College of Education, Enchi, Ghana, West Africa, ${ }^{2}$ Department of Science Education, Foso College of \\ Education, Assin Foso, Ghana, West Africa
}

*Corresponding Author: kerpack@yahoo.com

\section{ABSTRACT}

The purpose of the study was to explore the perceptions of teacher trainees on the use of think-pair-share in teaching and learning of classification of living organisms. The study adopted a quantitative approach. Both descriptive and inferential statistics were used to report the results of the study. Frequency counts and percentages were used to report the teacher trainees' perceptions about the impact of think-pair-share learning technique in the teaching and learning of classification of living organisms. The study was carried out in Enchi College of Education in the Aowin Municipality in the Western North Region of Ghana. Stratified, simple random, and systematic sampling techniques were used to select 80 respondents for the study. This was made up of 30 level 300 , 30 level 200 , and 20 level 100 students, respectively. The participants were subjected to think-pair-share learning technique of teaching. The instrument used for the data collection was a questionnaire guide. The findings of the study revealed that, think-pair-share learning technique of teaching motivate and engage, provide immediate feedback, develop social, and physical skills simultaneously, help students to learn with fun and increase students interest and confidence level. It was, therefore, recommended that creative approach such as think-pair-share learning technique should be adopted by science tutors in Colleges of Education for effective teaching and learning.

KEY WORDS: Think-pair-share; technique; pedagogic concept; cooperative learning; collaborative learning

\section{INTRODUCTION}

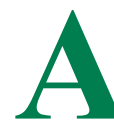

jiboye and Ajitoni (2008) observed that children learn best by being interested fully in their own work, by puzzling, experimenting, verifying their own suppositions, and drawing conclusions on the strength of evidence which they have collected themselves. Think-pair-share learning technique is a pedagogic concept which is aimed to provide students the achievement and to stimulate their energies and develop their abilities suitable for students of all ages and those engaging in cooperative learning for the first time (Ahmed, 2016).

Think-pair-share is a cooperative learning strategy that includes 3 time components, namely: Time for thinking, time for sharing with a partner, and time to share among pairs to a larger group. It is a collaborative learning strategy in which students work together to solve a problem or answer a question. This technique requires students to think individually about a topic or an answer to a question and share ideas with classmates. Using think-pairshare allows the teacher to gain insight into the quality of student understanding. When teachers are able to measure their students' understanding, they can use this information to alter their instruction in a way that would be more beneficial to learners.

Connelly (2010) posited that apart from a change in academic achievement, class wide peer tutoring also enhanced student motivation and promoted comprehension. Gooding and Merz's (2011) argued that students' attitudes toward Science changed completely after participating in the small peer-led collaborative group. Supportively, Yardim (2009) opines that after participating in the small peer-led collaborative groups, students' attitudes toward sciences changed completely. He asserted that the interactions among students enhanced their personal and academic skills due to more time spent together.

\section{LITERATURE REVIEW}

The think-pair-share pedagogy allows the teaching and learning process to be less teacher centered by giving more interdependence to students for participating in the activities by offering "processing time" and "wait-time" which greatly helps students to think deeper. This view is similar to what Yerigan (2008) writes that the "Think-Pair-Share is an active learning strategy that provides processing time for theory, builds in wait time, provides rehearsal, enhances depth and breadth of thinking, increases level of participation, allows the instructor to check for understanding and provides time for instructor to make instructional decisions" (p. 23). Its rationale has a lot in common with that of the constructivist approach as this model requires learners to interact with each other/others at different 
levels. Therefore, this model encourages learners to be more active during instruction.

According to the original model of think-pair-share, the think phase allows the teacher to pose a question to the class and gives students time to think individually and come up with original answers on their own; the pair phase requires students' pairing up preferably with the student sitting closest to them. At that point, depending on the type of the task and the question, students share their primary thoughts or answers with each other and the share phase, the paired students to share what they agree on with the whole class.

Utama et al. (2013) reported that the Think-Pair-Share approach allowed development of self-confidence and speaking skills among English language learners of which science learners cannot be rule out. They attributed this increase to the interaction and motivating effect this model brings. Jebur et al. (2012) found that implementation of this model resulted in higher learning results in a General Physics class. Similarly, Fitzgerald (2013) wrote that using Think-Pair-Share led to higher achievement results. Roswati and Radjab (2014) found out that implementing Think-Pair-Share pedagogy enabled their students to become better speakers of the target language in addition to fostering their motivation. McKeachie and Svinicki (2006) stated that following Think-Pair-Share activities, their students often felt more at ease to participate in a general discussion. Baleghizadeh (2010) found in his study that when his students in the second year of physics program worked with Think-Pair-Share pedagogy, their word-building abilities improved greatly. Likewise, the study by Sumarsih and Sanjaya (2013) revealed that applying Think-Pair-Share strategy improved the mean of students' scores in their writing class.

From the above, it can be deduced that there is a positive perception about the impact of think-pair-share technique on the learning process

\section{Perception on the Use of Think-Pair-Share Learning Technique}

Research has shown that cooperative learning increases students' understanding and ability to integrate and synthesize new material (Lujan and DiCarlo, 2005). Think-pair-share strategy is one way to incorporate cooperative learning into a classroom to give students the opportunity to process actively and develop a meaningful understanding of class material. Cooperative learning and the cooperative learning techniques, for example, think-pair-share, are being supported by educational theorist Vygotsky, the proponent of constructivism theory for teaching and learning. Constructivism stresses on active construction of knowledge by learners from their experiences (Fosnot, 1996; Steffe and Gale, 1995).

If students are paired together, they will be able to discuss each student's thought to get helpful feedback from the peer or one student may provide an appropriate model for the other student. That student would then have a better understanding of the topic (personal factor) to help the student to respond class discussions (Woolfolk, 2011).

Students' perceptions are the beliefs or opinions that they have as a result of realizing or noticing something, especially something that is perhaps not obvious to other people, for example: Teachers, parents, or outsiders. As stated by Wick and Pick (1978), there is a connection between perception and experience. They reported that perception and experience are related to one another. According to Gibson et al. (1985), perception is a cognitive process that individuals use to interpret and understand the world around them. Perception can be made through the cognitive process in our mind. Raba (2017) found that most students feel this technique is effective because they like working together. They feel more engaged and secure because it is not focusing on each one of them individually. Sometimes the students feel threatened or less confident when they work on their own. They emphasized that group work and peer work help to overcome communication problems since they learn from each other and help each other.

Since a think-pair-share session is always initiated to discuss a specific problem or idea, it should always be guided by the learning goal associated with the particular question or idea. Furthermore, think-pair-share pedagogy provides the opportunity for teachers to hear a wide range of students by circulating during the pairing stage and in class discussion. In addition to increased wait time, think-pair-share has shown to increase the number of students participating in class discussion (Rowe, 1972).

The study focused on how Ghanaian Colleges of Education teacher trainees perceive think-pair-share learning technique as a teaching strategy. The reason was that there has been little or no study conducted on teacher trainee's perception of think-pair-share learning technique in Colleges of Education in Ghana. This creates a literature gap, hence the current study. The study specifically sought to explore the perceptions of teacher trainees on the use of think-pair-share learning technique in teaching and learning of Classification of living organisms in Enchi College of Education in Ghana.

\section{METHODOLOGY}

The study adopted a quantitative approach. Frequency counts and percentages were used to report the teacher trainees' perceptions about the impact of think-pair-share learning technique of teaching. For simplicity and clarity, results are presented in tables. The data collected on think-pair-pair learning technique by the researchers through questionnaire guide was analyzed by the use of SPSS version 21.0 based on the themes arrived at in the data collection. The data analysis was guided by the research question "To what extent would think-pair-share learning technique improve teacher trainees" performance in Classification of living organisms in Enchi College of Education in Ghana?'

The population of the study were teacher trainees in Enchi College of Education in Ghana. The principles of voluntary 
participation, confidentiality, anonymity, and privacy as ethical issueswere considered by the researchers. Stratified, simple random, and quota sampling technique were used to sample 80 respondents. This was made up of 40 male teacher trainees and 40 female teacher trainees. The research instrument used to gather data for the study was self-designed questionnaire guide titled "Perception of Teacher Trainees on the use of think-pairshare learning technique" based on the topic treated. It was divided into two sections. Section A had six questionnaire guide items (1-6) and Section B had four items (7-10). The responses to the items were in five Likert options of strongly agree, agree, neutral, disagree, and strongly disagree. The content validity of the questionnaire was ascertained by subjecting the instrument to the scrutiny by colleagues. The instrument was pilot-tested on 20 participants from Wiawso College of Education since it shares similar geographical area with Enchi College of education culture to ascertain its validity and reliability.

\section{Pre-intervention}

Before the implementation, the participants were asked to write down their expectations for the use of think-pair-share learning technique. This enabled the researchers to verify whether their expectations have been met after the treatments were given.

\section{Intervention}

The intervention of the study lasted for 4 weeks with a 3-h lesson per week. The think-pair-share learning technique was used by the researchers to teach the participants classification of living organisms. In all, the whole lesson was taught in four weeks made up of 12 hours.

During the process, questions like who was the first person to have created a classification system for living organisms; The person who gave us the classification system that we still use today was; the process of grouping things based on the similarities is called......; and the correct term for a "two-part naming system" is... were offered to participants to excite their thinking to search for a solution. The participants were asked to think alone to resolve the issue or problem at hand within a given time frame. The participants were then asked to split up into pairs and discuss what they thought about the problem posed to them to share, exchange views and ideas to reach a common answer. Each pair then joined another paired group to share, exchange views and ideas to reach a common answer till all the participants had interacted with each other.

\section{Post-intervention}

After the treatment, the questionnaire guide on think-pair-share technique was administered to participants through some selected teachers, and retrieved through same teachers. This was done to ensure high coverage, completion, and return rate.

\section{RESULTS}

Table 1a reveals that 40 respondents strongly agreed that thinkpair-share learning technique motivated and engaged them during teaching and learning process, 36 respondents agreed that think-pair-share motivated and engaged them during teaching and learning process. However, 1 respondent responded neutral on that think-pair-share learning technique motivated and engaged him/her during teaching and learning process while 2 disagreed that think-pair-share learning technique motivated and engaged them during teaching and learning process and 1 respondent strongly disagreed, respectively, that think-pair-share learning technique motivated and engaged them during teaching and learning process.

It is clear from Table 1a that, 34 respondents strongly agreed that think-pair-share learning technique provided immediate feedback to them during teaching and learning process. 42 agreed that think-pair-share learning technique provided immediate feedback to them during teaching and learning process. None of the respondent responded neutral to the statement that think-pair-share learning technique provided immediate feedback to them. Again, two respondents disagreed that think-pair-share learning technique provided immediate feedback to them while two respondents disagreed and two strongly disagreed respectively that think-pair-share learning technique provided them immediate feedback during teaching and learning process. The responses of the majority (76) who strongly agreed and agreed, respectively, to the statement is in line with the assertion of Yerigan (2008) when he said that "the think-pair-share is an active learning strategy that provides processing time for theory, builds in wait time, provides rehearsal, enhances depth and breadth of thinking, increases level of participation, allows the instructor to check for understanding and provides time for instructor to make instructional decisions" (p. 23).

From Table 1a, it is evident that 28 respondents strongly agreed that think-pair-share learning technique helped them to develop social and physical skills simultaneously. Furthermore, 46 respondents agreed that think-pair-share learning technique helped them to develop social and physical skills simultaneously, 3 respondents responded neutral to the statement that think-pair-share learning technique helped them to develop social and physical skills simultaneously. Furthermore, 3 respondents disagreed that think-pair-share learning technique helped them to develop social and physical skills simultaneously, respectively, whiles none of the respondents strongly disagreed that think-pair-share learning technique helped them to develop social and physical skills simultaneously.

Table 1a revealed that 37 respondents strongly agreed that think-pair-share learning technique enabled them to learn with fun. 28 respondents agreed that think-pair-share learning technique enabled them to learn with fun and 4 respondents remained neutral on the assertion that thinkpair-share learning technique enabled them to learn with fun. However, 5 respondents and 6 respondents disagreed and strongly disagreed, respectively, that think-pair-share learning technique enabled them to learn with fun, respectively.

On the opinion of the respondents on whether think-pairshare learning technique had increased their interest as 
Table 1a: Perception of teacher trainees on the use of think-pair-share technique in teaching and learning of classification of living organisms

\begin{tabular}{|c|c|c|c|c|c|c|}
\hline Statement Responses & Strongly Agree (SA) & Agree (A) & Neutral (N) & Disagree (D) & Strongly Disagree (SD) & Total \\
\hline $\begin{array}{l}\text { Think-pair-share learning technique } \\
\text { motivated and engaged me during teaching } \\
\text { and learning process }\end{array}$ & 40 & 36 & 1 & 2 & 1 & 80 \\
\hline $\begin{array}{l}\text { Think-pair-share learning technique } \\
\text { provided immediate feedback to } \mathrm{m}\end{array}$ & 34 & 42 & 0 & 2 & 2 & 80 \\
\hline $\begin{array}{l}\text { Think-pair-share learning technique helped } \\
\text { me to develop social and physical skills } \\
\text { simultaneously }\end{array}$ & 28 & 46 & 3 & 3 & 0 & 80 \\
\hline $\begin{array}{l}\text { Think-pair-share learning technique } \\
\text { enabled me to learn with fun }\end{array}$ & 37 & 28 & 4 & 5 & 6 & 80 \\
\hline $\begin{array}{l}\text { Think-pair-share learning technique } \\
\text { increased my interest in the lesson }\end{array}$ & 44 & 36 & 0 & 0 & 0 & 80 \\
\hline $\begin{array}{l}\text { I felt confident in my abilities in the topic } \\
\text { when think-pair-share learning technique } \\
\text { was used for the lesson delivery }\end{array}$ & 42 & 30 & 3 & 2 & 3 & 80 \\
\hline
\end{tabular}

Table 1b: Perception of teacher trainees on the use of think-pair-share technique in teaching and learning of classification of living organisms

\begin{tabular}{|c|c|c|c|c|c|c|}
\hline Statement Responses & Strongly Agree (SA) & Agree (A) & Neutral (N) & Disagree (D) & Strongly Disagree (SD) & Total \\
\hline $\begin{array}{l}\text { I felt confident in my ability to contribute } \\
\text { to class discussion during the lesson when } \\
\text { think-pair-share learning technique was } \\
\text { used the lesson delivery }\end{array}$ & 35 & 45 & 0 & 0 & 0 & 80 \\
\hline $\begin{array}{l}\text { I collaborated with other teacher trainees } \\
\text { during the learning process when the } \\
\text { think-pair-share learning technique was } \\
\text { used for the lesson delivery }\end{array}$ & 37 & 36 & 0 & 3 & 4 & 80 \\
\hline $\begin{array}{l}\text { I had the opportunity to learn from other } \\
\text { teacher trainees when the think-pair-share } \\
\text { lesson delivery }\end{array}$ & 36 & 34 & 2 & 4 & 4 & 80 \\
\hline $\begin{array}{l}\text { I enjoyed sharing my thought and } \\
\text { observation with other teacher } \\
\text { trainees during class discussions when } \\
\text { think-pair-share learning technique was } \\
\text { used for the lesson }\end{array}$ & 38 & 32 & 2 & 4 & 4 & 80 \\
\hline
\end{tabular}

indicated in Table 1a, 44 respondents strongly agreed whereas 36 respondents agreed that think-pair-share learning technique has increased their interest. However, none of the respondents indicated neutral, disagreed, and strongly disagreed to the statement that think-pair-share learning technique has increased their interest.

A cursory look at this response indicates that all the respondents (80) teacher trainees confirmed that think-pair-share has increased their interest in the lesson. This assertion is supported by Ajiboye and Ajitoni (2008) who said that children learn best by being interested fully in their own work, by puzzling, experimenting, verifying their own suppositions and drawing conclusions on the strength of evidence which they have collected themselves as indicated in the literature review.

It is clear from Table 1a that, 42 respondents strongly agreed that think-pair-share learning technique helped them to feel confident in their abilities in classification of living organisms when think-pair-share learning technique was used to deliver the lesson. Furthermore, 30 respondents agreed that think-pairshare learning technique helped them to feel confident in their abilities in classification of living organisms when think-pairshare learning technique was used to deliver the lesson and 3 respondents responded neutral to the statement that thinkpair-share learning technique helped them to feel confident in their abilities in classification of living organisms when thinkpair-share learning technique was used to deliver the lesson. However, 2 respondents disagreed and three respondents strongly disagreed that think-pair-share learning technique helped them to feel confident in their abilities in classification of living organisms when think-pair-share learning technique was used to deliver the lesson.

It is also clear from Table $1 \mathrm{~b}$ that, 35 respondents strongly agreed that they felt confident in their ability to contribute to class discussion during the lesson when the think-pairshare learning technique was used for the lesson delivery. Furthermore, 45 respondents agreed that they felt confident in 
their ability to contribute to class discussion during the lesson when the think-pair-share learning technique was used for the lesson delivery. None of the respondents responded neutral, disagreed and strongly disagreed to the statement that they felt confident in their ability to contribute to class discussion during the lesson when the think-pair-share learning technique was used for the lesson delivery. The responses derived from all the 80 respondents above suggest that they felt confident in their abilities in the topic taught when think-pair-share was used for the lesson delivery. This is in line with Ahmed (2016) assertion that think - pair-share strategy is a modern teaching strategy which is aimed to provide students the achievement, stimulate their energies and develop their abilities.

Table $1 \mathrm{~b}$ reveals that 37 respondents strongly agreed that they collaborated with other teacher trainees during the learning process when think-pair-share learning technique was used for the lesson delivery. 36 respondents agreed that they collaborated with other teacher trainees during the learning process when think-pair-share learning technique was used for the lesson delivery. None of the respondents responded neutral on whether they collaborated with other teacher trainees during the learning process when think-pair-share learning technique was used for the lesson delivery. However, 3 respondents disagreed and 4 strongly disagreed that they collaborated with other teacher trainees during the learning process when think-pair-share learning technique was used for the lesson delivery, respectively.

The responses given above really suggest that the majority (73) of the respondents collaborated with each other during the learning process when the think-pair-share learning technique was used for the lesson delivery.

On the opinions of respondents on whether they had the opportunity to learn from other teacher trainees when thinkpair-share learning technique was used for the lesson delivery as indicated in Table $1 \mathrm{~b}$, it was revealed that 36 respondents strongly agreed and 34 respondents agreed that they had the opportunity to learn from other teacher trainees when think-pair-share learning technique was used for the lesson delivery. Furthermore, 2 respondents neither strongly agreed, agreed, disagreed, and strongly disagreed that they had the opportunity to learn from other teacher trainees when think-pair-share learning technique was used for the lesson delivery. However, 4 respondents disagree and 4 respondents strongly disagree that they had the opportunity to learn from other teacher trainees when think-pair-share learning technique was used for the lesson delivery.

Table $1 \mathrm{~b}$ again revealed that, 38 and 32 respondents strongly agreed and agreed that they enjoyed sharing their thoughts and observations with other teacher trainees during class discussion when the think-pair-share learning technique was used for the lesson delivery, respectively. Furthermore, 2 respondents responded neutral on the assertion that they enjoyed sharing their thoughts and observations with other teacher trainees during class discussion when the think-pair-share learning technique was used for the lesson delivery. However, 4 and 4 respondents disagreed and strongly disagreed, respectively, that they enjoyed sharing their thoughts and observations with other teacher trainees during class discussion when the think-pair-share learning technique was used for the lesson delivery, respectively.

\section{FINDINGS}

The analysis of Table 1a revealed that; out of 80 teacher trainees who were taught by the use of think-pair-share learning technique:

- 76 of the respondents were of the view that think-pairshare learning technique motivated and engaged them during teaching and learning process.

- $\quad 76$ of the respondents said that think-pair-share learning technique provided immediate feedback to them.

- 74 of the respondents confirmed that think-pair-share learning technique helped them to develop social and physical skills simultaneously.

- 65 of the respondents affirmed that think-pair-share learning technique enabled them to learn with fun when it was used during the teaching and learning process.

- 80 of the respondents confirmed that their interest was increased when think-pair-share learning technique was used during teaching and learning process.

- $\quad 72$ of the respondents were of the view that they felt confident in their abilities in the topic taught when thinkpair-share learning technique was used during teaching and learning process.

Again, it came to light from the analysis of Table $1 \mathrm{~b}$ that:

- 80 of the respondents felt confident in their abilities to contribute to class discussion during the lesson when think-pair-share learning technique was used during teaching and learning process.

- 73 of the respondents were of the view that they collaborated with other teacher trainees when think-pair-share learning technique was used during teaching and learning process.

- 70 of the respondents had the opportunity to learn from other teacher trainees when think-pair-share learning technique was used during teaching and learning process.

- 70 of the respondents enjoyed sharing their thoughts and observations during class discussions when think-pair-share learning technique was used during teaching and learning process.

These findings confirmed the assertion made by Connelly (2010); Gooding and Merz (2011) and Yardım (2009) that the use of think-pair-share learning technique of teaching in the teaching and learning of science effectively engages and motivates students with little intrinsic interest, promote, comprehension and affects the attitudes and performance of students positively.

\section{CONCLUSIONS AND RECOMMENDATIONS}

The results obtained from this study are sufficient to conclude that there is some level of improvement on the performance 
of teacher trainees when think-pair-share learning technique was adopted to teach classification of living organisms in science lessons.

It also came to light from the study that most teacher trainees were motivated and engaged, received immediate feedback, developed social and physical skills simultaneously, learnt with fun, interest was increased, felt confident in their abilities in the topic taught, felt confident in their abilities to contribute to class discussion, collaborated with other teacher trainees, had the opportunity to learn from other teacher trainees, enjoyed sharing their thoughts and observations during class discussions when think-pair-share technique was used during teaching and learning process.

In the light of these findings, it is important that creative approaches such as think-pair-share learning technique should be adopted by science tutors in Colleges of Education for effective teaching and learning since they motivate and engage, provide immediate feedback, develop social and physical skills simultaneously, help students to learn with fun and increase students interest and confidence level.

\section{REFERENCES}

Ahmed, M.A. (2016). The effect of (think pair share) and (sequenced questions) strategies on fifth primary students achievement and retention at sciences. Journal of College of Basic Education, 22(94), 403-442.

Ajiboye, J.O., \& Ajitoni, S.O. (2008). Effects of full and quasi participatory learning strategies on Nigerian senior secondary students' environmental knowledge: Implication for classroom practice. International Journal of Environmental and Science Education, 3, 58-66.

Baleghizadeh, S. (2010). The effect of pair work on a word-building task. Elt Journal, 64(4), 405-413.

Connelly, D.J. (2010). The Extent that Class Wide Peer Tutoring Impacts Student Motivation, Comprehension and Academic Achievement. New Jersey: Unpublished Master's Thesis, Caldwell College.

Fitzgerald, D. (2013). Employing think-pair-share in associate degree nursing curriculum. Teaching and Learning in Nursing, 8(3), 88-90.

Fosnot, C.T. (1996). Constructivism: Theory, Perspective, and Practice.
New York: Teachers College Press.

Gibson, J.L., Ivanovich, J.M., \& Donnely, J.H. (1985). Organizations. Behavior, Structure, Processes. Plano, Tex: Business Publications, Inc.

Gooding, J., \& Metz, B. (2011). From misconceptions to conceptual change. The Science Teacher, 78(4), 34-37.

Jebur, M.S., Jasim, H.H., \& Jaboori, H.R. (2012). The effect of using think-pair-share technique on EFL students' achievement in the course of general English. Journal of College of Basic Education, 15(80), 823-838.

Lujan, H., \& DiCarlo, S.E. (2005). Too much teaching, not enough learning: What is the solution? Advances in Physiology Education, 30(1), 17-22.

McKeachie, W.J., \& Svinicki, M. (2006). McKeachie's Teaching Tips: Strategies, Research and Theory for College and University Teachers. $12^{\text {th }}$ ed. Boston, Massachusetts: Houghton Mifflin.

Raba, A.A.A. (2017). The influence of think pair share on improving students' oral communication skills in Efl classrooms. Creative Education, 8(1), $12-23$.

Roswati, Z.M., \& Radjab, D. (2014). Improving students' speaking skill by using think-pair-share strategy at the second semester of syariah class a at language center of UinSuska Riau. English Language Teaching, 2(1), $1-12$.

Rowe, M.B. (1972). Wait-Time and Rewards as Instructional Variables: Their Influence on Language, Logic, and Fate Control. Chicago, Illinois: Paper Presented at the National Association for Research in Science Teaching.

Steffe, S.S., \& Gale, E. (1995). Teacher evaluation: The limits of looking. Educational Researcher, 13(9), 11-18.

Sumarsih, M.P., \& Sanjaya, D. (2013). TPS as an effective technique to enhance the students' achievement on writing descriptive text. English Language Teaching, 6(12), 106-113.

Utama, I.P., Marhaeni, A., \& Putra, I.N. (2013). The Effect of Think Pair Share Teaching Strategy to Students' Self-confidence and Speaking Competency of the Second Grade Students of SMPN 6. SINGARAJA e-Journal of Postgraduate Program, University of Education, Ganesha. English Study Program of Education. pp. 1-10.

Wick, M., \& Pick, M. (1978). Ecological Study of Learning. New York: Harper and Row.

Woolfolk, A. (2011). Educational Psychology: Active Learning. $11^{\text {th }}$ ed. Boston: Bollyn and Bacon.

Yardım, H.G. (2009). Promoting effective helping behaviour in Peer-directed Groups. International Journal of Educational Research, 39(4), 73-97.

Yerigan, T. (2008). Getting active in the classroom. Journal of College Teaching and Learning, 5(6), 19-24. 